\title{
Performance and Governance of Swiss Pension Funds
}

\author{
Manuel Ammann And Andreas ZingG*
}

June, 2008

\begin{abstract}
We investigate the relationship of pension fund governance and investment performance. For this purpose, we develop the Swiss Pensoin Fund Governance Index (SPGI) which is a standard metric for the governance quality of Swiss pension funds. The empirical analysis is based on a sample of 96 pension funds with total assets of more than CHF 190 billion. We find evidence for governance issues in the area organization and target setting. Our results support the widespread hypothesis of a positive relationship between pension fund governance and investment performance.
\end{abstract}

\section{Introduction}

Some few cases of mismanagement and fraud in the Swiss occupational pension scheme have put pension fund governance in the spotlight of public interest. Pension fund governance has taken center stage in public debate also in other countries like Germany, the Netherlands, or the U.K. ${ }^{1}$. The public and political debate on pension fund governance is often centered around the misuse of pension assets. However, pension fund governance has a much broader scope and includes overall management, organizational design and decision-making processes. Taking such a holistic view, the Organisation for Economic Cooperation and Development (OECD) has adopted guidelines for pension fund governance in April 2005 (OECD (2002)). The guidelines contain 12 fundamental principles and aim at setting international standards for the governance

${ }^{*}$ University of St. Gallen, Swiss Institute of Banking and Finance, Rosenbergstrasse 52, 9000 St. Gallen. Phone: +41-71-224-70-90. E-mail: manuel.ammann@unisg.ch, andreas.zingg@unisg.ch. We would like to thank Alexander Ising, Stephan Süss and Evert Wipplinger for their helpful comments. Swisscanto Holding AG is gratefully acknowledged for providing the data sample.

${ }^{1}$ Myners (2001) investigates institutional investments in the UK and sets out 10 principles of good practice. 
of corporate pension funds. In Switzerland, the Swiss Pension Fund Association (ASIP) and the Swiss Insurance Association (SVV) adopted a code of conduct already in the year 2000. However, the code of conduct confines itself to preventing the misuse of pension assets.

Previous research is mainly dedicated to theoretical best practice solutions and concepts for the governance of pension fund. Ambachtsheer and Ezra (1998) and Ambachtsheer (2007) provide a comprehensive governance framework for U.S. pension funds. Brandenberger and Hilb (2008) describe a holistic and practical governance framework for Swiss pension funds. In contrast, empirical research on the relation between pension fund governance and investment performance is scarce. Ambachtsheer, Capelle, and Scheibelhut (1998) find a positive correlation between governance quality and pension fund performance. However, they use a subjective governance metric that is based on the governance quality perceived by pension fund CEOs.

In this paper, we develop a standardized and objective metric that measures the quality of a pension fund's governance. For this purpose, we construct a governance index for Swiss pension funds. The Swiss Pension Fund Governance Index (SPGI) relates to the most recent research on the governance of pension funds as well as the current standards and best practice codes such as the OECD guidelines for pension fund governance. Applying the SPGI, we investigate the current governance quality of Swiss pension funds. We conduct a survey among 500 Swiss pension funds and determine the SPGI value for each individual pension fund. Finally, we test for any statistical relationship between governance quality, measured by the SPGI, and the investment performance of pension funds.

The article is structured as follows: In Section 2, we review the previous research on pension fund governance. Section 3 provides a brief description of legal requirements relevant to pension fund governance. In Section 4, we develop and describe the Swiss Pension Fund Governance Index (SPGI). Section 5 provides an initial overview and characterization of our data sample and provides an assessment of the current pension fund governance quality in Switzerland. The empirical results on the relation of pension fund governance and investment returns are presented in Section 6. Finally, Section 7 draws the final conclusions.

\section{Literature}

While literature on corporate governance has proliferated in recent years, the governance of pension funds has attracted less attention. The majority of the existing literature on pension fund governance is dedicated to the development and description of best practice solutions and concepts for pension funds. In contrast, there is only limited empirical research on the relation between governance and performance of pension funds. 
Ambachtsheer, Capelle, and Scheibelhut (1998) and Ambachtsheer and Ezra (1998) were among the first to investigate the statistical relationship between governance quality and investment performance. They develop a questionnaire that asks pension fund CEOs to score statements about their governance quality. The authors report a positive correlation between the resulting "CEO score" and investment performance. Ambachtsheer, Capelle, and Lum (2007) and Ambachtsheer (2007) corroborate these findings with a newer data sample. According to their analysis, the impact of governance from good to bad may be as much as 100 to 300 basis points per year. However, the findings are subject to some important caveats. The proxy for the governance quality, the "CEO score", is based on self-reported scores. It remains unclear whether the causality runs from the perceived governance quality to investment performance. It could also be the other way around with good (bad) achieved investment performance leading to perceived good (bad) governance quality. Thus, the perceived governance quality does not necessarily correlate positively with the effective governance quality. Finally, there is a tendency in surveys of this nature to rate on the high side. As a result, the "CEO score" is likely to give a biased view of the effective quality of pension fund governance.

Some authors investigate how the investment performance of pension funds is related to particular governance variables such as the composition of the board of trustees. Yang and Mitchell (2005) investigate the effect of several organizational and structural pension fund features on the investment performance. They find evidence that the composition of the board of trustees as well as the reporting practices influence the investment performance of public pension funds. Mitchell and Hsin (1994) confirm that the composition of public pension fund boards is significantly associated with performance. Useem and Mitchell (2000), in contrast, find no direct relation between the governance quality and the investment performance. However, they show that governance has a direct effect on how pension funds invest their assets. The investment strategy, in turn, directly affects the investment performance. The authors conclude that governance quality indirectly affects the investment performance of pension funds. Finally, Besley and Prat (2003) apply agency theory to find the optimal governance structure of defined contribution and defined benefit pension plans. They analytically prove that pension fund governance matters.

Due to the lack of a standardized and objective metric that measures the governance quality of pension funds as well as the lack of data, many authors confine themselves to developing best practice recommendations for pension fund governance without providing empirical evidence. Ambachtsheer and Ezra (1998), Ambachtsheer (2007), and Brandenberger and Hilb (2008) provide comprehensive governance frameworks for U.S. and Swiss pension funds. They cover all aspects of pension fund governance such as organizational coherence, staff performance evaluation, investment controlling and communication. The OECD guidelines for pension fund governance are less concrete and practical. In return, the 12-point guidelines are not country-specific and 
mark therefore, the first initiative to set international standards for the governance of pension funds. The guidelines propose a governance structure with shared responsibility and built-in checks and balances, such as regular reviews by an independent party. Clapman (2007) identifies several governance-related problems in U.S. pension funds and recommends best practice governance principles to deal with them. He provides recommendations for an optimal board composition and proposes clear lines of authority as well as regular staff performance evaluations. Board composition and its decision-making capacity is also seen as crucial by Clark, Caerlewy-Smith, and Marshall (2006) and Clark, Caerlewy-Smith, and Marshall (2007). Finally, Clark and Urwin (2007) propose 12 principles of best-practice such as organizational coherence, effective and performance-linked compensation practices, and decision-making systems that function in real-time not calender time.

In summary, it can be highlighted that previous research provides some evidence that good governance positively affects the investment performance of pension funds.

\section{Legal requirements relevant to pension fund governance}

In this section, we briefly describe the most important legal requirements affecting the governance of Swiss pension funds ${ }^{2}$. Switzerland is one of the few countries with a mandatory occupational pension scheme. The affiliation of employees with a pension plan is in the responsibility of the employer. Since employees do not have the right to opt out of a pension fund and can exert little influence on the details of their pension insurance, the Swiss Federal Law on Occupational Old-age, Survivors' and Disability Pension Plan (LPP) defines minimum standards to ensure a certain minimum benefit level. Furthermore, the law stipulates that pension funds must be legally separated from the sponsoring company.

To ensure a minimum benefit level, the LPP stipulates minimum contributions that vary according to age. Furthermore, Swiss pension funds have to guarantee a certain minimum return on the mandatory savings capital of active contributors on a yearly basis. In addition, the LPP stipulates a minimum conversion rate, with which the individual savings capital is converted into an annual pension annuity for defined contribution plans. The liabilities are not only determined by the statutory minimum interest rate but also by the so-called technical interest rate. The technical interest rate is the assumed discount rate used for the calculation of the present value of future contributions and liabilities ${ }^{3}$. As a result, a defined contribution plan has to

\footnotetext{
${ }^{2}$ See Helbling (2006) for a more detailed description of the Swiss occupational pension scheme.

${ }^{3}$ The Pension Rights Transfer Act stipulates a technical interest rate between 3.5 and
} 
guarantee the statutory minimum interest rate on the savings capital of the active contributors and, as an implicit guarantee, the technical interest rate on the pensioners' covering capital. A defined benefit plan has to implicitly guarantee the technical interest rate both to the active contributors and the pensioners. Considering administration costs and provisions for longevity and value fluctuation reserves, an average Swiss pension fund currently requires an annual investment return between 4 and 5 percent to keep its financial balance ${ }^{4}$.

In most cases, Swiss pension funds are governed by a board of trustees that is ultimately responsible for managing and overseeing the pension fund in the best interests of plan members and beneficiaries. The board of trustees is able to delegate certain functions for example, to a chief executive officer or to subcommittees. However, the ultimate management and oversight responsibility cannot be delegated but remains always with the board of trustees. It must be pointed out that board members are personally liable for any losses and damages caused willfully.

According to the LPP, employees and employers must have equal representation in the board of trustees. In Switzerland, as in many other countries, there is no legal requirement for board members to have any particular level of expertise such as know-how in investment matters. In addition, the selection process for board members is not regulated by the LPP. While there is no empirical evidence on the level of competence of Swiss pension fund trustees, Myners (2001) points to significant shortcomings in the knowledge and understanding of pension fund trustees in the U.K..

The LPP contains regulations to which Swiss pension funds must comply for their investments. Pension fund assets have to be managed prudently to ensure the safety of assets, achieve a reasonable return on investments, maintain a suitable diversification of risks, and allow for the liquidity requirements of the plan ${ }^{5}$. To comply with the "safety principle", pension funds invest their assets in such a way that liabilities are covered preferably any time ${ }^{6}$. For this purpose, most pension funds accumulate variability reserves which help to smoothen out fluctuations on investment returns. In addition, Swiss pension funds face quantitative limitations on their investments in equities, bonds, mortgages and real estate. Since the year 2000, it has become clear that quantitative limitations can be exceeded if the pension fund can justify them as

$4.5 \%$.

${ }^{4}$ Estimate is based on the following assumptions: statutory minimum interest rate of $2.5 \%$ on the savings capital of active contributors, technical interest rate of $3.75 \%$ on the pensioners'covering capital, provisions for longevity and fluctuation reserves of $0.5 \%$ in each case and administration costs of $0.3 \%$.

${ }^{5}$ Article 71 of the Swiss Federal Law on Occupational Old-age, Survivors' and Disability Pension Plan (LPP). In addition, Articles 49-60 of the Ordinance on the Occupational OldAge, Survivors' and Disability Benefit Plans (OOB2).

${ }^{6}$ The Swiss regulator temporarily tolerates underfunding of pension funds to a level of $90 \%$. 
part of a prudent investment policy according to the Article 59 of the Ordinance on the Occupational Old-Age, Survivors' and Disability Benefit Plans (OOB2). Recent surveys ${ }^{7}$ uncover that almost 80 percent of Swiss pension funds utilize the prudent investor rule and exemptions from the quantitative limitations thus have become the rule.

\section{Swiss Pension Fund Governance Index}

In this section we develop a standard metric that measures the governance quality of Swiss pension funds. For this purpose, we construct the Swiss Pension Fund Governance Index (SPGI). The SPGI is based on empirical findings of previous research, best practice solutions and concepts proposed in the literature, and own considerations of the authors. The index takes values between 0 and 65 points with better-governed pension funds having higher index levels. The SPGI consists of six sub-indices capturing the governance quality with regard to organization (10 points), target setting and management objectives (10), investment strategy (9), investment rules and organization (7), controlling and steering (26), and communication (3). To ensure easy application of the SPGI, we constrain ourselves to objective and measurable index constituents. However, we are well aware that good governance includes soft factors that are not considered in our index. We describe the composition of each of the six SPGI sub-indices in the following sub-sections.

\subsection{Organization}

The SPGI Organization, the SPGI sub-index measuring the organizational design quality, takes values between 0 and 10. Table 1 provides the detailed composition of the first SPGI sub-index.

Clear lines of authority minimize misunderstandings and give rise to an efficient decision-making process. Clapman (2007) and Clark and Urwin (2007) confirm that clear lines of authority are a principal component of good governance. Similarly, the OECD guidelines postulate clear identification and assignment of responsibilities. To comply with good governance, pension funds therefore require organizational regulations (index point 1 ) that clearly identify and assign the most important areas of responsibilities to the different pension fund bodies. In addition, we concur with Brandenberger and Hilb (2008) and state that the most important responsibilities should to be detailed in a function chart $(2)^{8}$.

Recent developments in the capital markets reveal that pension funds require decision-making systems that function in real-time not in calender time,

\footnotetext{
${ }^{7}$ Compare 8th edition of the Swiss Institutional Survey (Lusenti (2007)).

${ }^{8} \mathrm{~A}$ function chart shows the different management levels of a pension fund (e.g., board of trustees, investment committee, CEO) and their relation (e.g., decision, implementation, control) to individual tasks and competences.
} 
as pointed out by Clark and Urwin (2007). To ensure a qualified real-time decision-making process, it is recommended that pension funds install a fulltime chief executive officer (3). Thus, day-to-day management and, in particular, routine controlling duties can be delegated to the chief executive officer. We are aware that small and even medium-sized pension funds may potentially be unable to afford a full-time chief executive officer on their payroll. In such a case, pension funds could consider outsourcing day-to-day management to an external provider. Alternatively, members of the board of trustees could specialize in certain areas such as benefits, investments and legal requirements to ensure qualified and effective decision-making ${ }^{9}$.

Table 1: Composition of the sub-index SPGI Organization

The Swiss Pension Fund Governance Index (SPGI) consists of 6 sub-indices. The sub-index SPGI Organization takes values between 0 and 10 with better-governed pension having higher values. The sub-index measures the governance quality with regard to organization based on 10 objective and measurable criteria.

\begin{tabular}{|c|c|c|}
\hline Best Practice & Assessment criteria & $\overline{\text { SPGI }}$ \\
\hline \multirow[t]{2}{*}{ Clear lines of authority } & Organizational regulations & 1 \\
\hline & Function chart & 1 \\
\hline \multirow{4}{*}{$\begin{array}{l}\text { Effectiveness and effi- } \\
\text { ciency of management } \\
\text { decisions }\end{array}$} & Full-time chief executive officer (CEO) & 1 \\
\hline & Separate investment committee & 1 \\
\hline & $\begin{array}{l}\text { Number of board members equal to or less } \\
\text { than } 6\end{array}$ & 1 \\
\hline & $\begin{array}{l}\text { Number of investment committee members } \\
\text { equal to or less than } 6\end{array}$ & 1 \\
\hline \multirow{2}{*}{$\begin{array}{l}\text { Securing and enhance- } \\
\text { ments of internal skills } \\
\text { and capabilities }\end{array}$} & $\begin{array}{l}\text { Knowledge-based election/appointment of } \\
\text { board members }\end{array}$ & 1 \\
\hline & Education concept & 1 \\
\hline \multirow[t]{2}{*}{$\begin{array}{l}\text { Direct access to exter- } \\
\text { nal know-how }\end{array}$} & $\begin{array}{l}\text { Immediate access of the board to external } \\
\text { specialist(s) }\end{array}$ & 1 \\
\hline & $\begin{array}{l}\text { Immediate access of the investment commit- } \\
\text { tee to external specialist(s) }\end{array}$ & 1 \\
\hline Total & & 10 \\
\hline
\end{tabular}

Hess and Impavido (2003) argue that boards of corporations not only divide their work but also assign responsibility for such work to separate committees.

\footnotetext{
${ }^{9}$ If there is no chief executive officer, specialization of the board of trustees gives 0.5 index points.
} 
We believe that pension funds should set up at least one sub-committee responsible for investment matters (4) such as the selection of external asset managers or decisions on the tactical asset allocation. The investment committee may meet more frequently than the board of trustees thus enabling fast decision-making processes. Furthermore, the appointment of investment committee members can be solely based on expertise since equal representation of employers and employees is in Switzerland only required for the board of trustees.

Corporate governance research suggests that large boards can be less effective than smaller boards. Jensen (1993) and Lipton and Lorsch (1992) find a negative size effect in boards of seven or more members. Yermack (1996) corroborates these findings. For pension funds, Impavido (2002) postulates that the number of board members should be limited to maximize the effectiveness of the board. We believe that corporate governance research is applicable to pension funds. Therefore, the SPGI rewards pension funds with boards (5) and investment committees (6) consisting of not more than 6 members.

Board composition is perceived as one of the key issues by many authors (e.g., Ambachtsheer (2007), Clark (2007), Clark, Caerlewy-Smith, and Marshall (2007)). To comply with good governance, a board of trustees must consist of adequately qualified and experienced individuals. However, since all stakeholders such as employers, unions and old age beneficiaries wish to be represented in the board of trustees, there is a natural trade-off between representation and expertise. We agree with Clark, Caerlewy-Smith, and Marshall (2007) and postulate that members of the board of trustees should be solely selected for their expertise. Therefore, the SPGI rewards pension funds that have no ex officio members in their board of trustees (7). Furthermore, trustees, on a regular basis, should obtain educational training with a view to providing and improving core competencies of importance for pension fund management. Therefore, we postulate that pension funds should have a concept on educational training (8).

In case the board of trustees or the investment committee does not have the sufficient expertise, direct access to external know-how is of great importance. This is supported by the OECD guidelines and by Clark, Caerlewy-Smith, and Marshall (2007). Therefore, our governance index rewards pension funds that have independent experts in their board of trustees (9) and in their investment committee (10).

\subsection{Target setting and management objectives}

The second SPGI sub-index measures the governance quality with regard to target setting and management objectives. The SPGI Target Setting takes values between 0 and 10 index points, as shown in Table 2 .

The ultimate goal of a pension fund is to provide a secure retirement income to its plan members. To be able to achieve the ultimate goal, there should 
be clear transparency on the target of financing. This implies that pension funds have transparency on the minimum return that is required to keep their financial balance (index point 1). The estimate of the minimum required return net of asset management costs should at least consider guaranteed interest on pension liabilities, longevity risk, accumulation of value fluctuation reserves ${ }^{10}$, and administration costs (2). Since all of these parameters can change over time, the minimum required returns needs to be reviewed at least on an annual basis (3) according to Brandenberger and Hilb (2008).

\section{Table 2: Composition of the sub-index SPGI Target Setting}

The Swiss Pension Fund Governance Index (SPGI) consists of 6 sub-indices. The sub-index SPGI Target Setting takes values between 0 and 10 with better-governed pension having higher values. The sub-index measures the governance quality with regard to target setting and management objectives based on 10 objective and measurable criteria.

\begin{tabular}{|c|c|c|}
\hline Best Practice & Assessment criteria & SPGI \\
\hline \multirow{3}{*}{$\begin{array}{l}\text { Clear transparency on } \\
\text { the target of financing }\end{array}$} & Transparency on the minimum required return & 1 \\
\hline & $\begin{array}{l}\text { Estimate of the minimum required return con- } \\
\text { siders all pivotal influencing factors }\end{array}$ & 1 \\
\hline & Annual review of the minimum required return & 1 \\
\hline \multirow{3}{*}{$\begin{array}{l}\text { Feasible and measur- } \\
\text { able management objec- } \\
\text { tives }\end{array}$} & Binding objectives for the board of trustees & 1 \\
\hline & $\begin{array}{l}\text { Functional specifications for the chief execu- } \\
\text { tive officer (CEO) }\end{array}$ & 1 \\
\hline & $\begin{array}{l}\text { Binding objectives for the chief executive offi- } \\
\text { cer (CEO) }\end{array}$ & 1 \\
\hline \multirow[t]{5}{*}{$\begin{array}{l}\text { Target-oriented incen- } \\
\text { tive structures }\end{array}$} & $\begin{array}{l}\text { Financial compensation for the board of } \\
\text { trustees members }\end{array}$ & 1 \\
\hline & Compensation of board of trustees members & 1 \\
\hline & linked to management objectives & \\
\hline & $\begin{array}{l}\text { Regular performance evaluation of the chief } \\
\text { executive officer (CEO) }\end{array}$ & 1 \\
\hline & Code of conduct implemented & 1 \\
\hline Total & & 10 \\
\hline
\end{tabular}

The OECD guidelines propose regular assessments of persons involved in the operation and oversight of the pension funds. However, regular assessments require measurable management objectives. Therefore, the SPGI rewards pension funds with binding objectives for the board of trustees (4). Hess and

\footnotetext{
${ }^{10}$ Accumulation of value fluctuation reserves is only relevant in case minimum required reserves are not yet fully funded.
} 
Impavido (2003) provide examples of potential board objectives such as improvement of the funding ratio, size of the investment return, and reducing administration costs. In addition, a job description (5) defining general tasks, functions and responsibilities is recommended for the chief executive officer. Based on the job description, the pension fund should define binding objectives for the chief executive officer preferably on a yearly basis (6).

Management objectives alone are not sufficient to encourage good decisionmaking. In line with the OECD guidelines, we believe that target-oriented incentive structures are required to comply with good governance. The SPGI rewards pension funds with financial compensation for the members of the board of trustees (7). On one hand, financial compensation for board members will help to attract highly qualified and experienced individuals. On the other hand, board members might feel a stronger obligation to spend time and resources on pension fund matters when they are financially compensated. In the U.K., Clark and Urwin (2007) find best practice examples of pension funds that do not only financially compensate their board members but also link the compensation to the mission and performance of the fund. This seems to be a promising approach also for Swiss pension funds. Therefore, the SPGI encourages a process that links the financial compensation of board members to the objectives of the board (8). This requirement is supported by Impavido (2002) and Hess and Impavido (2003). It is of high importance that incentive structures are also aligned with the objectives for the chief executive officer. Clapman (2007) proposes that pension funds should establish and maintain regular processes by which staff performance is measured. Therefore, the SPGI rewards such pension funds that conduct performance evaluations of the chief executive officer on a regular basis (9). Pension funds can thereby, often fall back on existing performance evaluation processes of the sponsoring company. Finally, incentive structures must ensure the proper use of pension assets and prevent misuse. To obtain the maximum of 10 index points, pension funds must therefore have implemented the rules and regulations of the Swiss Code of Conduct ${ }^{11}$ of the Swiss Pension Fund Association (ASIP) and the Swiss Insurance Association (SVV).

\subsection{Investment strategy}

The third SPGI sub-index allows for the assessment of the governance quality with regard to the investment strategy. The sub-index SPGI Investment Strategy takes values between 0 and 9 . Details on the composition of the sub-index are provided in Table 3 .

To comply with good governance, pension funds must align their investment strategy with their target of financing and their risk-taking capacity. On one hand, this implies an investment strategy that is appropriate to earn at

\footnotetext{
${ }^{11}$ The Code of Conduct was issued in the year 2000 and is designed to support the proper use of pension funds and prevent misuse.
} 
least the minimum required return in the long run. On the other hand, the current risk-taking capacity, measured by the funding ratio, determines the risk budget, which in turn, restricts the flexibility of choosing an investment strategy. The determination of the investment strategy is of such great importance that this decision should be based on a professional asset-liability study (index point 1), as proposed by Brandenberger and Hilb (2008).

Table 3: Composition of the sub-index SPGI Investment Strategy The Swiss Pension Fund Governance Index (SPGI) consists of 6 sub-indices. The sub-index SPGI Investment Strategy takes values between 0 and 9 with bettergoverned pension having higher values. The sub-index measures the governance quality with regard to investment strategy based on 9 objective and measurable criteria.

\begin{tabular}{|c|c|c|}
\hline Best Practice & Assessment criteria & SPGI \\
\hline \multirow{8}{*}{$\begin{array}{l}\text { Investment strategy } \\
\text { aligned with tar- } \\
\text { get of financing and } \\
\text { risk-taking capacity }\end{array}$} & $\begin{array}{l}\text { Investment strategy based on asset-liability } \\
\text { study }\end{array}$ & 1 \\
\hline & $\begin{array}{l}\text { Realistic estimate of the expected return of } \\
\text { the investment strategy }\end{array}$ & 1 \\
\hline & $\begin{array}{l}\text { Expected return of investment strategy } \\
\text { greater or equal than the minimum required } \\
\text { return }\end{array}$ & 1 \\
\hline & $\begin{array}{l}\text { Regular review of the expected return against } \\
\text { the minimum required return }\end{array}$ & 1 \\
\hline & $\begin{array}{l}\text { Realistic estimate of the minimum required } \\
\text { value fluctuation reserves }\end{array}$ & 1 \\
\hline & $\begin{array}{l}\text { Existing value fluctuation reserves greater or } \\
\text { equal than the minimum required value fluc- } \\
\text { tuation reserves }\end{array}$ & 1 \\
\hline & $\begin{array}{l}\text { Utilization of the existing value fluctuation } \\
\text { reserves }\end{array}$ & 1 \\
\hline & $\begin{array}{l}\text { Tactical fluctuation margins around the } \\
\text { strategic asset allocation }\end{array}$ & 1 \\
\hline $\begin{array}{l}\text { Full utilization of de- } \\
\text { grees of freedom in the } \\
\text { legal requirements }\end{array}$ & Application of Article 59 OOB2 & 1 \\
\hline Total & & 9 \\
\hline
\end{tabular}

Furthermore, the SPGI insists on a realistic return expectation of the investment strategy (2). We use historic returns ${ }^{12}$ to assess the expected return

\footnotetext{
${ }^{12}$ See Table 17 and Table 18 for details on the benchmark indices used to assess the expected return.
} 
of the investment strategy specified by the pension funds in the survey. The expected return is judged as realistic when it is smaller than or equal to the historic return of the investment strategy. It should be taken into consideration that a tolerance margin of $5 \%$ is applied. Finally, the expected return must be greater than or equal to the minimum required return (3) to obtain another SPGI index point ${ }^{13}$. This important requirement ensures that the pension fund maintains its financial balance in the long run. In case the minimum required return is not specified in the survey or does not consider all pivotal influencing factors, we estimate the effective minimum required return ${ }^{14}$. Since both the return prospects of the investment strategy and the minimum required return can change over time, both parameters need to be reviewed on a regular basis (4).

Good governed pension funds follow investment strategies that are not only aligned with the minimum required return but also with the current risk-taking capacity. Since the funding ratio must not stay below $100 \%$ over a longer period of time, pension funds accumulate reserves to smoothen out fluctuations on investment returns. To comply with good governance, pension funds should have a realistic estimate of the minimum required value fluctuation reserves (5). Since the LPP does not stipulate a calculation methodology, we use value-atrisk $^{15}$ to assess the minimum required value fluctuation reserves that pension funds specify in the survey. The minimum required value fluctuation reserves are assessed as realistic when they are greater than or equal to our valueat-risk based estimate. Again, we apply a tolerance margin of 5\%. For an investment strategy to be aligned with the risk-taking capacity of the pension fund, existing value fluctuation reserves have to be greater than or equal to the minimum required reserves (6). On the other hand, excess reserves should be either utilized or passed down to the plan members. Therefore, the SPGI rewards pension funds that have excess reserves smaller than or equal to $5 \%$ in terms of liabilities (7). In reality, the effective asset allocation often deviates from the strategic asset allocation since asset classes show different investment returns. To avoid the effective asset allocation containing a risk profile in excess of the risk-taking capacity of the fund, we postulate that good governed pension funds define tactical fluctuation margins around the strategic asset allocation (8). Finally, the SPGI rewards pension funds that fully utilize the degrees of freedom in the legal requirement by making use of the possibilities of expanding

\footnotetext{
${ }^{13}$ If the expected return is assessed as not realistic, we compare the historic return of the investment strategy with the minimum required return.

${ }^{14}$ The estimate of the minimum required return is based on a statutory minimum interest rate of $2.5 \%$, the technical interest rate as provided by the pension funds, provisions for longevity of $0.5 \%$, and administration costs of $0.3 \%$. If the required value fluctuation reserves are not yet fully funded another $0.5 \%$ is added.

${ }^{15}$ We determine the reserves with which the funding ratio will not fall below $100 \%$ within 1 year with a $99 \%$ probability. Further input parameters are the expected return and the volatility of the investment strategy. If the expected return is not assessed as realistic, we apply historic returns. The volatility of the investment strategy is based on the historic returns of the benchmark indices described in the appendix.
} 
the investment universe according to the Article 59 OOB2 (9). However, this implies that the risk-taking capacity of the pension fund is sufficient.

\subsection{Investment rules and organization}

The fourth SPGI sub-index measures the governance quality with regard to investment rules and organization and takes values between 0 and 7 . Table 4 provides the detailed composition of the sub-index SPGI Investment Rules and Organization.

Table 4: Composition of the sub-index SPGI Investment Rules and Organization

The Swiss Pension Fund Governance Index (SPGI) consists of 6 sub-indices. The sub-index SPGI Investment Rules and Organization takes values between 0 and 7 with better-governed pension having higher values. The sub-index measures the governance quality with regard to investment rules and organization based on 5 objective and measurable criteria.

\begin{tabular}{lll}
\hline Best Practice & Assessment criteria & SPGI \\
\hline $\begin{array}{l}\text { Clear regulation of the } \\
\text { investment process }\end{array}$ & $\begin{array}{l}\text { Investment regulations } \\
\text { Investment regulations cover all pivotal ele- } \\
\text { ments of the investment process }\end{array}$ & 3 \\
$\begin{array}{l}\text { Systematic investment } \\
\text { reasoning }\end{array}$ & Detailed analysis of asset structuring & 1 \\
$\begin{array}{l}\text { Transparent selection of } \\
\text { external asset managers }\end{array}$ & $\begin{array}{l}\text { Clear process for evaluating and selecting ex- } \\
\text { ternal managers } \\
\text { Catalogue of criteria for the evaluation of ex- }\end{array}$ & 1 \\
& $\begin{array}{l}\text { ternal managers } \\
\text { Total }\end{array}$ & 7 \\
\hline
\end{tabular}

The implementation of the investment strategy requires in a first step a clear regulation of the investment process. For this purpose, pension funds normally define investment regulations (index point 1). Brandenberger and Hilb (2008) provide an overview of the key elements of best practice investment regulations. Best practice investment regulations should cover objectives and general principles, investment organization ${ }^{16}$, investment guidelines ${ }^{17}$, and con-

\footnotetext{
${ }^{16}$ The investment organization governs the duties and competencies associated with the investment process.

${ }^{17}$ The investment guidelines govern the investment strategy, the investment style, the investment form, and the approved investment instruments.
} 
trolling and reporting $(2 \text { and } 3)^{18}$. In addition, investment regulations should govern accounting, loyalty in asset management, and the exercise of voting rights $(4)^{19}$.

Furthermore, the implementation of the investment strategy requires a detailed investment reasoning, as proposed by Clark and Urwin (2007) and Monk (2007). Therefore, the SPGI insists on a detailed analysis of the asset structuring (5). This analysis implies important decisions such as active versus passive investment style or direct mandates versus collective investment vehicles.

The last step in the implementation of the investment strategy is the selection of asset managers. Manager selection is of great importance but sensitive at the same time since conflicts of interests might exist. Therefore, a transparent selection of external asset managers is imperative. This implies a clear and traceable process for evaluating and selecting external managers (6). In addition, we postulate that pension funds should have a predefined catalogue of criteria for the evaluation of external managers (7).

\subsection{Controlling and steering}

The fifth SPGI sub-index indicates the governance quality of pension funds with regard to controlling and steering. As shown in Table 5 and Table 6 , the sub-index contributes a maximum of 26 index points to the SPGI. Thus, it is the largest of the six sub-indices.

It is highly imperative to the safety of the retirement income that the board of trustees approaches and solves problems in a timely manner. This requires that target deviations are identified and understood as early and as fast as possible. Therefore, Brandenberger and Hilb (2008) state that a comprehensive management information system is essential for a pension fund. An information concept ${ }^{20}$ builds always the basis of a management information system (index point 1). Brandenberger and Hilb (2008) provide an excellent overview of information and data that should be provided by a management information system. The SPGI proposes that the following management information be made available on a monthly basis $(2-9)^{21}$ : estimate of the current funding ratio, effective asset allocation, performance of total assets, policy return $^{22}$, performance per asset class, performance of respective benchmark indices per asset class, performance per mandate, and performance of the

\footnotetext{
${ }^{18}$ Investment regulations, objectives and general principles, investment organization, and investment guidelines are each rewared with $1 / 2$ index points.

${ }^{19}$ Accounting, loyalty regulations in asset management and exercising voting rights are each rewarded with $1 / 3$ index points.

${ }^{20}$ An information concepts governs the acquisition of information, the information content, the information frequency, and the recipients.

${ }^{21}$ Monthly availability of information is rewarded with 1 index point, quarterly availability with 0.5 indexpoints and semi-annual availability with 0.25 index points.

${ }^{22}$ The policy return is the return that would have been earned had the strategic asset allocation been consistently followed and implemented passively before deduction of any costs.
} 
respective benchmark indices per mandate. For the sake of clarity, this information should be available in a consolidated report (10).

All these information allow for a comprehensive assessment of the current financial situation. To obtain a forward-looking perspective, we propose annual projections of the funding situation (11). A simple way of doing such a projection is to calculate forward-looking confidence intervals for the funding ratio of the next 12 or 24 months applying different safety levels such as $90 \%$, $95 \%$ or $99 \%$. Brandenberger and Hilb (2008) propose a convincing approach to graphically illustrate the results of such a projection. Furthermore, the authors propose to run historical projections for difficult years such as the year 2002 with a big stock market slump. Our index incorporates this proposal and rewards pension funds that run forward-looking stress tests (12).

Table 5: Composition of the sub-index SPGI Controlling and Steering (part I)

The Swiss Pension Fund Governance Index (SPGI) consists of 6 sub-indices. The sub-index SPGI Controlling and Steering takes values between 0 and 26 with bettergoverned pension having higher values. The sub-index measures the governance quality with regard to controlling and steering based on 19 objective and measurable criteria.

\begin{tabular}{|c|c|c|}
\hline Best Practice & Assessment criteria & SPGI \\
\hline \multirow{7}{*}{$\begin{array}{l}\text { Comprehensive man- } \\
\text { agement information } \\
\text { system }\end{array}$} & Information concept & 1 \\
\hline & $\begin{array}{l}\text { Key management information available on a } \\
\text { monthly basis }\end{array}$ & 8 \\
\hline & $\begin{array}{l}\text { Management information available in a con- } \\
\text { solidated report }\end{array}$ & 1 \\
\hline & Annual projections of the funding situation & 1 \\
\hline & $\begin{array}{l}\text { Stress tests included in the projections of } \\
\text { funding situation }\end{array}$ & 1 \\
\hline & Designated investment controller & 1 \\
\hline & $\begin{array}{l}\text { Regular information on the developments of } \\
\text { the financial markets for the board and in- } \\
\text { vestment committee members }\end{array}$ & 1 \\
\hline \multirow[t]{2}{*}{$\begin{array}{l}\text { Regular } \\
\text { checks }\end{array}$} & $\begin{array}{l}\text { Annual assessment of compliance with re- } \\
\text { strictions of asset management mandates }\end{array}$ & 1 \\
\hline & Annual assessment of compliance with laws & 1 \\
\hline
\end{tabular}

Impavido (2002) postulates that performance evaluations should be conducted by independent entities on a regular basis. The SPGI considers the request for independent controlling resources and rewards pension funds that have a dedicated (internal or external) investment controller (13). The latter 
should not be in charge of any management or oversight responsibilities beyond the investment controlling to avoid potential conflicts of interests. In addition to the above-mentioned information, board members as well as members of the investment committee should be informed on the developments of the financial markets on a regular basis (14). Since decentralized information collection is not an efficient way, information on the development of the financial markets should be compiled and synthesized by a central entity such as the investment controller.

One further element of best practice controlling processes are regular compliance checks. OECD guidelines provide for the regular assessment of compliance with laws. However, to comply with good governance, the SPGI insists not only on regular assessments of compliance with laws (15) but also on compliance checks with regard to restrictions of asset management mandates (16) such as maximum tracking errors or approved investment instruments.

\section{Table 6: Composition of the sub-index SPGI Controlling and Steering} (part II)

The Swiss Pension Fund Governance Index (SPGI) consists of 6 sub-indices. The sub-index SPGI Controlling and Steering takes values between 0 and 26 with bettergoverned pension having higher values. The sub-index measures the governance quality with regard to controlling and steering based on 19 objective and measurable criteria.

\begin{tabular}{|c|c|c|}
\hline Best Practice & Assessment criteria & SPGI \\
\hline \multirow{5}{*}{$\begin{array}{l}\text { In-depth root cause } \\
\text { analysis }\end{array}$} & Performance analysis & 1 \\
\hline & Performance attribution & 1 \\
\hline & Risk attribution & 1 \\
\hline & Regular cost control & 1 \\
\hline & $\begin{array}{l}\text { Regular cost benchmarking against peer } \\
\text { group }\end{array}$ & 1 \\
\hline \multirow{6}{*}{$\begin{array}{l}\text { Action-oriented and } \\
\text { real-time management } \\
\text { decisions }\end{array}$} & At least 6 meetings of the board of trustees & 1 \\
\hline & per annum & 1 \\
\hline & $\begin{array}{l}\text { At least } 12 \text { meetings of the investment com- } \\
\text { mittee per annum }\end{array}$ & \\
\hline & $\begin{array}{l}\text { Management reporting includes recommen- } \\
\text { dations for corrective measures }\end{array}$ & 1 \\
\hline & $\begin{array}{l}\text { Intervention guidelines in case of violations } \\
\text { of the tactical fluctuation margins }\end{array}$ & 1 \\
\hline & $\begin{array}{l}\text { Interventions guidelines in case of a signifi- } \\
\text { cant deterioration of the funding ratio }\end{array}$ & 1 \\
\hline Total & & 26 \\
\hline
\end{tabular}


While problem identification makes up just one side of the coin, problemsolving requires an in-depth root-cause-analysis to understand existing target deviations. We therefore, propose to conduct a basic set of deviation analyses on a regular basis. Pension funds are recommended to conduct performance analysis (17) across all asset classes and mandates to obtain a risk-adjusted view on the performance of their assets. A performance attribution (18) helps pension funds to identify sources of performance deviations such as timing and selection ability of the portfolio manager. To get a better understanding of their investment risks, pension funds should finally accomplish risk attribution (19) that includes a decomposition of risk into sources of systematic and specific risks or into various factors such as industry or currency.

Costs are important because they reduce the rate of return on investments (Bikker and de Dreu (2006)). Therefore, pension funds should have transparency on the development of their administration and asset management costs. The SPGI postulates costs controls on a regular basis (20). To facilitate a better assessment of the cost-efficiency, administration and asset management costs should additionally be benchmarked against other comparable pension funds (21).

Well-governed pension funds are not immune to target deviations but they identify and approach problems in a timely manner. However, only actionoriented real-time decisions bring the pension fund back on track. This requires that governing bodies of a pension fund, in particular the board of trustees and the investment committee, meet regularly. In the light of the great responsibility, a meeting interval of once in every two months by the board of trustees is deemed appropriate (22). Given the fast changing dynamics of the capital markets, the investment committee should meet more often. We therefore suggest a meeting frequency of once each month for the investment committee (23). However, having a full-time chief executive officer allows a lesser meeting frequency ${ }^{23}$. To ensure effective and efficient decision-making in the board and investment committee meetings, management reporting should contain fact-based recommendations for corrective measures (24), as proposed by Brandenberger and Hilb (2008). These recommendations may be developed by the chief executive officer or by the investment controller.

Certain situations, such as a significant deterioration of the funding ratio in combination with high stock market volatilities, require fast decision-making. At the same time, decision-making in such exceptional circumstances requires intensive preparation and leads often to controversial discussions in the board. We therefore, agree with Brandenberger and Hilb (2008) and recommend the definition of intervention guidelines for the case of violations of the tactical fluctuation margins (25) and a significant deterioration of the pension fund's risk-taking capacity (26).

\footnotetext{
${ }^{23}$ If the pension fund employs a full-time chief executive officer, the board of trustees should meet at least once per quarter and the investment committee every two month.
} 


\subsection{Communication}

The SPGI Communication is the sixth sub-index. As the name indicates, the sub-index measures the governance quality of pension funds with regard to communication. The sub-index takes values between 0 and 3 , as shown in Table 7 .

The OECD guidelines propose disclosure of information to active plan participants and beneficiaries. This is supported by Impavido (2002). The author postulates that all plan members should receive information on the objectives of the fund, its agenda to achieve the stated objectives, and the rights of the plan members. We support broad disclosure of information. However, there are additional dialog partners besides pension fund members. Therefore, the SPGI rewards pension funds with a communication concept (1) governing the information content and channels for the different dialog groups such as employers, unions, or media. Even though there are many dialog partners, pension fund members remain the key addressees. Therefore, pension fund members should receive information on important activities and results on a regular basis (2). We believe that a quarter-yearly interval for the circulation of information is adequate (3).

Table 7: Composition of the sub-index SPGI Communication

The Swiss Pension Fund Governance Index (SPGI) consists of 6 sub-indices. The sub-index SPGI Communication takes values between 0 and 3 with better-governed pension having higher values. The sub-index measures the governance quality with regard to controlling and steering based on 3 objective and measurable criteria.

\begin{tabular}{|c|c|c|}
\hline $\begin{array}{l}\text { Best Practice } \\
\text { Ongoing communica- } \\
\text { tion with key dialog } \\
\text { partners }\end{array}$ & Assessment criteria & $\overline{\text { SPGI }}$ \\
\hline \multirow{3}{*}{$\begin{array}{l}\text { Ongoing communica- } \\
\text { tion with key dialog } \\
\text { partners }\end{array}$} & Communication concept & 1 \\
\hline & $\begin{array}{l}\text { Regular information of plan members on im- } \\
\text { portant activities and results }\end{array}$ & 1 \\
\hline & Quarterly information frequency & 1 \\
\hline Total & & 3 \\
\hline
\end{tabular}

In summary, it can be stated that the SPGI is based on tangible and therefore objectively measurable governance components. This is of great importance for the scoring of individual pension funds since we intend to create an objective governance metric that does not rely on the perception of pension fund representatives. We are well aware that our index does therefore, not cover all aspects of best practice pension fund governance. In particular, the index does not consider soft factors that cannot be objectively measured such as board member competence or skills of pension fund staff. Furthermore, the index cannot make full allowance for the great diversity of pension funds in Switzerland. Nevertheless, we believe that that pension funds have common- 
alities and that the SPGI is therefore a reasonable indicator for the governance quality of Swiss pension funds.

\section{Governance quality of Swiss pension funds}

In this section, we use the SPGI to assess the governance quality of Swiss pension funds. For this purpose, we conduct a survey among 500 Swiss pension funds. We received completed questionnaires from 96 pension funds. This is an acceptable response rate of about $19 \%$. The summary statistics of our data sample are provided in Table 8.

Table 8: Summary statistics of the pension fund data sample Number, assets, plan type and legal form of the 96 pension funds in our data sample in comparison to the pension fund universe in Switzerland. Summary statistics are as of the year-end 2006 .

\begin{tabular}{lrr} 
& Data sample & Universe \\
\hline Pension funds & 96 & 2,140 \\
& & \\
Assets (CHF million) & 193,696 & 570,340 \\
Assets per pension fund (CHF million) & 2,018 & 267 \\
& & \\
Defined contribution plans & $(67 \%)$ & $(89 \%)$ \\
Defined benefit plans & $(33 \%)$ & $(11 \%)$ \\
& & \\
Private pension funds & $(81 \%)$ & $(95 \%)$ \\
Public pension funds & $(19 \%)$ & $(5 \%)$ \\
\hline
\end{tabular}

Our sample can be considered representative with respect to pension funds assets. With assets of about CHF 194 billion as of the year-end 2006, pension funds in our sample account for about one third of pension funds assets in Switzerland ${ }^{24}$. On the contrary, our sample is not deemed representative as far as the number of pension funds is concerned. Our sample covers just between $4 \%$ and $5 \%$ of registered pension funds in Switzerland. As a result, the sample is heavily biased towards larger pension funds. As shown in Table 8 , the average pension fund size in our sample is more than CHF 2 billion compared to an average of CHF 267 million across all registered pension funds in Switzerland. However, the median size of CHF 495 million indicates that the average size in our sample is strongly influenced by a few very large pension funds. Indeed, it must be kept in mind that our sample also includes very small pension funds such as the smallest fund in the sample with assets of only

\footnotetext{
${ }^{24}$ According to the 2006 pension funds statistics of the Swiss Federal Statistical Office.
} 
CHF 2.6 million. Finally, defined benefit plans and public pension funds are over-represented in our sample.

The bias of our sample towards larger pension funds, defined benefit plans and public pension funds may affect the overall assessment of the governance quality of Swiss pension funds. On the contrary, these selection biases have no impact on the analysis of the statistical relationship between the quality of governance and performance since we control for size, plan type and legal form. With regard to the overall assessment of the governance quality, we expect the size to be a real constraint on the quality of governance since the implementation and maintenance of several SPGI constituents is associated with significant resources and costs. It therefore goes that the overall governance quality of Swiss pension funds may be over-estimated in the face of the selection bias towards larger pension funds. To have a better understanding of the effect of this selection bias therefore, we carry out further investigation of the relationship between size and governance quality in the next section. The effect of the selection bias with respect to plan type and legal form remains unclear and is also subject to be further investigation in the next section.

\subsection{Scoring system}

In this section, we describe how completed questionnaires are translated into SPGI score values by index component and pension fund. To make score values comparable and as objective as possible, pension funds were not asked to provide any self-assessments of their governance quality. We share the concerns, raised by Ambachtsheer, Capelle, and Lum (2007), that self-reported scores may be a biased indicator of the effective governance quality. For this reason, we constructed the SPGI such that self-assessments of pension funds are not required for the attribution of individual score values. On the contrary, pension funds were asked in the questionnaire to provide pure facts. Based on these facts, we attributed score values by index component and pension fund.

The questionnaire covers all SPGI assessment criteria described in Section 4. The vast majority of these assessment criteria, such as a full-time chief executive officer or financial compensation for the board of trustees, can be covered by yes/no questions. In such a case, the answers are directly converted into index points. However, some assessment criteria, such as optimal board size or consideration of all pivotal elements for the minimum required return estimate, cannot be covered by yes/no questions. In such cases, we ask for additional information, such as the number of board members, or provide a selection of potential answers such as interest liabilities, longevity as pivotal elements for the minimum required return estimate. The answers to these questions are then indirectly converted into index points as described in Section 4.

In summary, it can be stated that our score values are not based on perceived governance quality of pension funds. On the contrary, the score values 
are directly or indirectly derived from answers to yes/no questions or from pure facts provided by pension funds in the questionnaire. As a result, the score values should be an unbiased indicator of the effective governance quality of pension funds. On the other hand, we omit all soft factors of good governance that cannot be objectively measured.

\subsection{Survey results}

As shown in Table 9, pension funds achieve, on average, 42.8 index points or $66 \%$ of the SPGI maximum (65 index points). Index values in the sample range from low 17.5 to high 59.5 index points. We find some evidence for potential governance issues in the areas of organization and target setting. Some of the potential governance issues are highlighted below.

As in other countries, board composition seems to be one of the key issues in Switzerland according to our survey. More than 70 percent of the pension funds in the sample have boards beyond the optimal size. The average board size in the sample is between 9 and 10 with the ultimate impact of rendering effective decision-making difficult. Moreover, board of trustees often include several ex officio members that are not primarily appointed because of their expertise. An additional weak point is direct access to external know-how. More than 75 percent of the pension funds in the sample do not have external experts in the board of trustees. At least half of the pension funds have external experts in the investment committee. At the positive end, the majority of pension funds has a chief executive officer and a separate investment committee with an average size between 4 and 5 members.

Target setting is the second area for which our index indicates major governance issues. A significant part of the pension funds in the sample seems to have limited transparency on the minimum required return. Although all but one pension fund specify a minimum required return in the questionnaire, a high share of 40 percent does not consider all pivotal influencing factors and may therefore underestimate the minimum required return. Management objectives for the board of trustees seem to be the exception rather than the rule. Only 18 percent of the pension funds define objectives for the board of trustees. Furthermore, the majority of pension funds does not compensate their board members financially. In the face of the huge responsibility inherent in board membership, this is a somewhat surprising result. Contrary to the governance literature and positive experiences in other countries (Clark and Urwin (2007)), none of the pension funds links the financial compensation of the board members to target achievement.

As shown in Table 9, the governance quality with regard to the investment strategy measured by the SPGI seems to be at the high end. The vast majority of pension funds has realistic return expectations of the investment strategy. However, in more than 20 percent of cases, the investment strategy is expected to yield, on average, returns below the minimum required return. In such a 


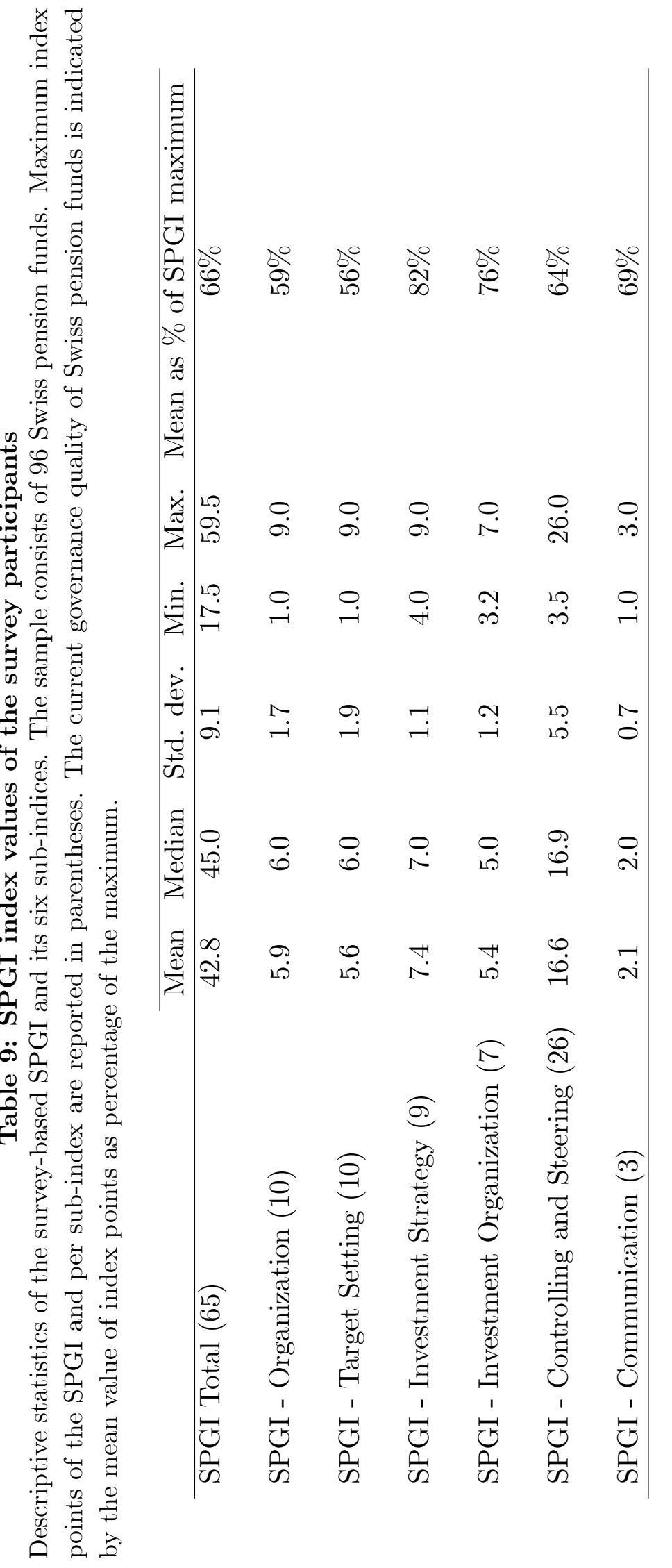


case, the financial stability of the pension funds is not guaranteed in the long run. This is an alarming result given that only half of the pension funds in our sample have value fluctuation reserves at the desired level.

The sub-index SPGI Investment Rules and Organization indicates high governance standards of Swiss pension funds with respect to the investment organization. Nevertheless, we find governance issues for the selection of external asset managers. Only about 40 percent of the pension funds in the sample have a pre-defined process for selecting and evaluating external managers. Even though the selection of external managers is of great importance, the majority of pension funds seems not to have a catalogue of criteria for the evaluation of external managers.

The meeting frequency seems to be another key issue for Swiss pension funds according to our survey. Only one out of every three investment committees meets on a monthly basis or once in every two months, where there is a full-time chief executive officer. Regarding the meeting frequency of the board of trustees, almost 50 percent of the pension funds in the sample do not comply with the SPGI governance standards. Given the fast dynamics of the capital markets, a higher meeting frequency seems to be recommendable. In contrast, the management information systems of Swiss pension funds meet rather high standards. On average, most important management information is available at least on a quarterly basis. However, there are pension funds in the sample that have no management information available on a regular basis. Without regular and reliable information on the financial situation of the pension fund, the board of trustees can actually not comply with their requirements and the safety of the retirement income is not guaranteed. We find that almost 50 percent of the pension funds in the sample do not employ a designated investment controller. For these pension funds, the independence of investment controlling, which is an important element of good governance, is not guaranteed. The lack of designated controlling resources might also explain why numerous pension funds do not conduct deviation analyses on a regular basis. It remains unclear whether these pension funds are able to define effective measures in case of target deviations.

On the whole, there are no indications of serious governance issues with Swiss pension funds. However, it must be kept in mind that our sample is biased towards larger pension funds and size seems to be a real constraint on governance. Therefore, we are up against the risk of overestimating the effective governance quality of Swiss pension funds. In addition, since the survey is on a voluntary basis, willingness to participate on the part of pension funds could imply that they belong to the "high quality end" of a much larger universe of pension funds. 


\section{Relation between governance quality and in- vestment performance}

In this section, we investigate the statistical relationship between pension fund governance, measured by the SPGI, and investment performance. For this purpose, data collected for the survey go beyond those required by the governance index. Information such as performance, size, plan type and costs are also gathered. The investigation is based on data of the years 2005 and 2006.

\subsection{Model}

In a first step we need to identify an appropriate performance measure. Literature suggests alpha as performance measure. However, pension funds have limited possibilities of directly influencing the alpha, in particular, when asset management is outsourced. The alpha is rather determined by the skills of the asset manager than by the governance quality of the pension fund. In addition, our sample contains only yearly performance data, making it difficult to estimate alphas. Therefore, we use a performance metric for measuring the value creation of pension funds. According to Ambachtsheer (1996) and Ambachtsheer, Capelle, and Scheibelhut (1998), value creation of pension funds comes from two fundamental sources: First, a strategic asset allocation generating returns above the minimum required returns on the liability side. The second source of value creation is an implementation strategy that creates additional returns by active asset management. Both the decision on the strategic asset allocation and the decision on the implementation style have implications on costs which have to be considered. Following Ambachtsheer (1996), we call our performance measure net value added (NVA). The NVA is calculated as follows:

$$
\begin{aligned}
\text { NVA }= & \text { Gross policy return } \\
& - \text { Minimum required return } \\
& +(\text { Gross fund return }- \text { Gross policy return }) \\
& - \text { Operating costs }
\end{aligned}
$$

Decision on the strategic asset allocation as an initial source of value creation is mirrored by the difference between the gross policy return and the minimum required return in Equation (1). Gross policy return is the estimated return that would have been earned if the strategic asset allocation had been implemented passively before the deduction of any costs. In our questionnaire we asked pension funds for their strategic asset allocation. To determine gross policy return we use standard benchmark indices ${ }^{25}$ and multi-

\footnotetext{
${ }^{25}$ See Table 17 for details on the benchmark indices used to calculate the gross policy return.
} 
ply the index returns with the strategic weights of the respective asset classes. As mentioned, minimum required returns were asked for in the survey. In case this return was not provided, or assessed as not realistic, we estimate the minimum required return ${ }^{26}$. The second decision that is of importance to the value creation of pension funds is represented by the difference between the gross fund return and the gross policy return. This difference is simply the outperformance or underperformance of the fund against its policy benchmark before costs. The sum of the asset allocation and the implementation component are now reduced by the operating $\operatorname{costs}^{27}$ in percent of total assets, as shown in Equation (1). This is due to the fact that both the decision on the strategic asset allocation and the implementation style affects asset management and partly administration costs.

The determinants of a pension fund's performance are manifold. To investigate the relationship between pension fund governance and performance we adopt the following model:

$$
\begin{aligned}
N V A= & c_{0}+c_{1} \cdot S P G I+c_{2} \cdot A D C O+c_{3} \cdot A M C O+c_{4} \cdot S I Z E+ \\
& c_{5} \cdot C O R A+c_{6} \cdot L E F O+c_{7} \cdot P L T Y,
\end{aligned}
$$

where $S P G I$ is our governance index. Given the empirical evidence on mutual fund performance, we expect costs to have an important influence on pension fund performance. Therefore, we include administration and asset management costs in our model. $A D C O$ represents administration costs and is defined as total costs of administration divided by total assets. Asset management costs, represented by the variable $A M C O$, are also expressed as percentage of total assets. Ambachtsheer, Capelle, and Scheibelhut (1998) report a significant relation between performance and pension fund size. Therefore, we include the variable $S I Z E$, which is the natural logarithm of total pension funds assets, in our performance equation. Furthermore, we expect the coverage ratio, $C O R A$, to have an influence on performance since it determines the pension fund's degrees of freedom with regard to the investment strategy. The legal form and the plan type might also have an influence on the performance. The legal form is represented by the dummy variable $L E F O$, which takes a value of 1 if the pension fund is under public law. Finally, PLTY represents the plan type. The dummy variable takes the value 1 in case of a defined contribution plan.

Correlations of the regression factors are reported in Table 10. In order to cope with the problem of multicollinearity, factors with correlations above 0.5 are orthogonalized before being used as regressors. Correlations provided

\footnotetext{
${ }^{26}$ The estimate of the minimum required return is based on a statutory minimum interest rate of $2.5 \%$, the technical interest rate as provided by the pension funds, provisions for longevity of $0.5 \%$, and administration costs of $0.3 \%$. If the required value fluctuation reserves are not yet fully funded another $0.5 \%$ is added.

${ }^{27}$ Operating costs are the sum of administration and asset management costs.
} 
in Table 10 allow for a first evaluation to determine if the selection biases of the sample affect the assessment of the governance quality provided in the previous section. As expected, size and governance quality are highly correlated. As a result, we are likely to overestimate the overall governance quality of Swiss pension funds. The effective governance quality of the total pension fund universe in Switzerland is expected to be lower. In contrast however, the legal form and the plan type are only marginally correlated with the SPGI. Therefore, the overrepresentation of defined benefit plans and public pension funds is not expected to have a significant influence on our assessment of the governance quality of Swiss pension funds. As already mentioned, the selection biases in our sample have no effect on the investigation of the statistical relationship between governance quality and performance since we control for size, plan type and legal form, as shown in Equation (2).

Table 10: Correlations of regression factors

Correlations of the factors explaining pension fund performance. SPGI is a standard metric for the governance quality of Swiss pension funds. ADCO represents the administration costs, AMCO the asset management costs. SIZE is the natural logarithm of total pension assets, CORA is the coverage ratio, LEFO the legal form and PLTY the plan type. The variables are based on a sample of 96 Swiss pension funds.

\begin{tabular}{lcccccc} 
& SPGI & ADCO & AMCO & SIZE & CORA & LEFO \\
\hline ADCO & -0.49 & 1.00 & & & & \\
AMCO & -0.14 & 0.18 & 1.00 & & & \\
SIZE & 0.62 & -0.68 & -0.49 & 1.00 & & \\
CORA & -0.17 & 0.01 & 0.07 & -0.20 & 1.00 & \\
LEFO & -0.01 & 0.01 & -0.17 & 0.23 & -0.35 & 1.00 \\
PLTY & -0.07 & 0.23 & 0.08 & -0.33 & 0.06 & -0.23 \\
\hline
\end{tabular}

\subsection{Empirical results}

The investigation of the relationship between pension fund governance and performance proceeds in three steps. First, we investigate the overall statistical relationship between pension fund governance and performance. Governance quality is thereby measured by the SPGI and its six sub-indices, performance is measured by the NVA. In a second step, we investigate the effect of good governance on the two individual sources of value creation separately. Finally, we analyze the influence of individual governance mechanisms such as a chief executive officer or a designated investment controller on the performance of pension funds. Our investigation is based on the model described by Equation $(2)$ 


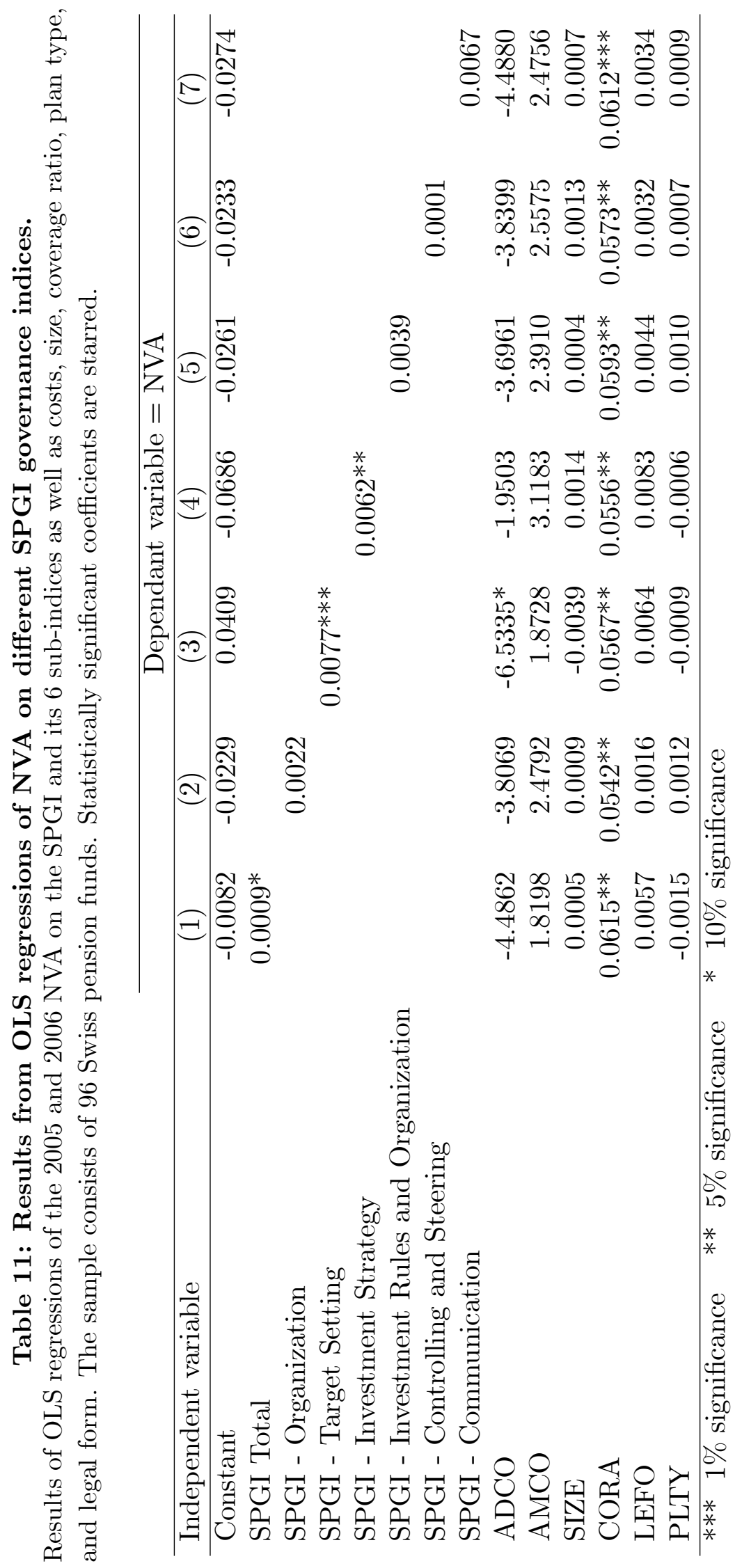




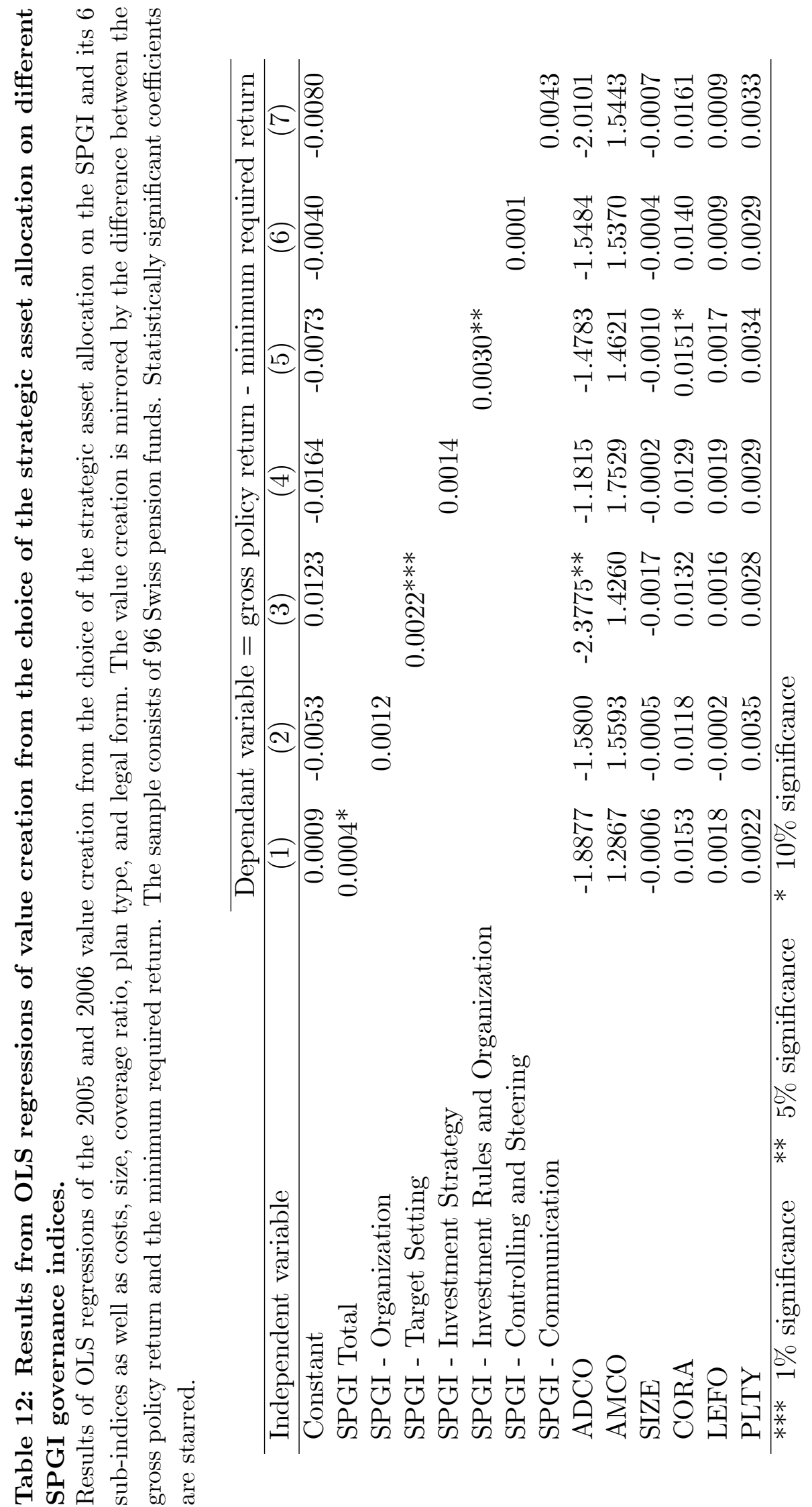




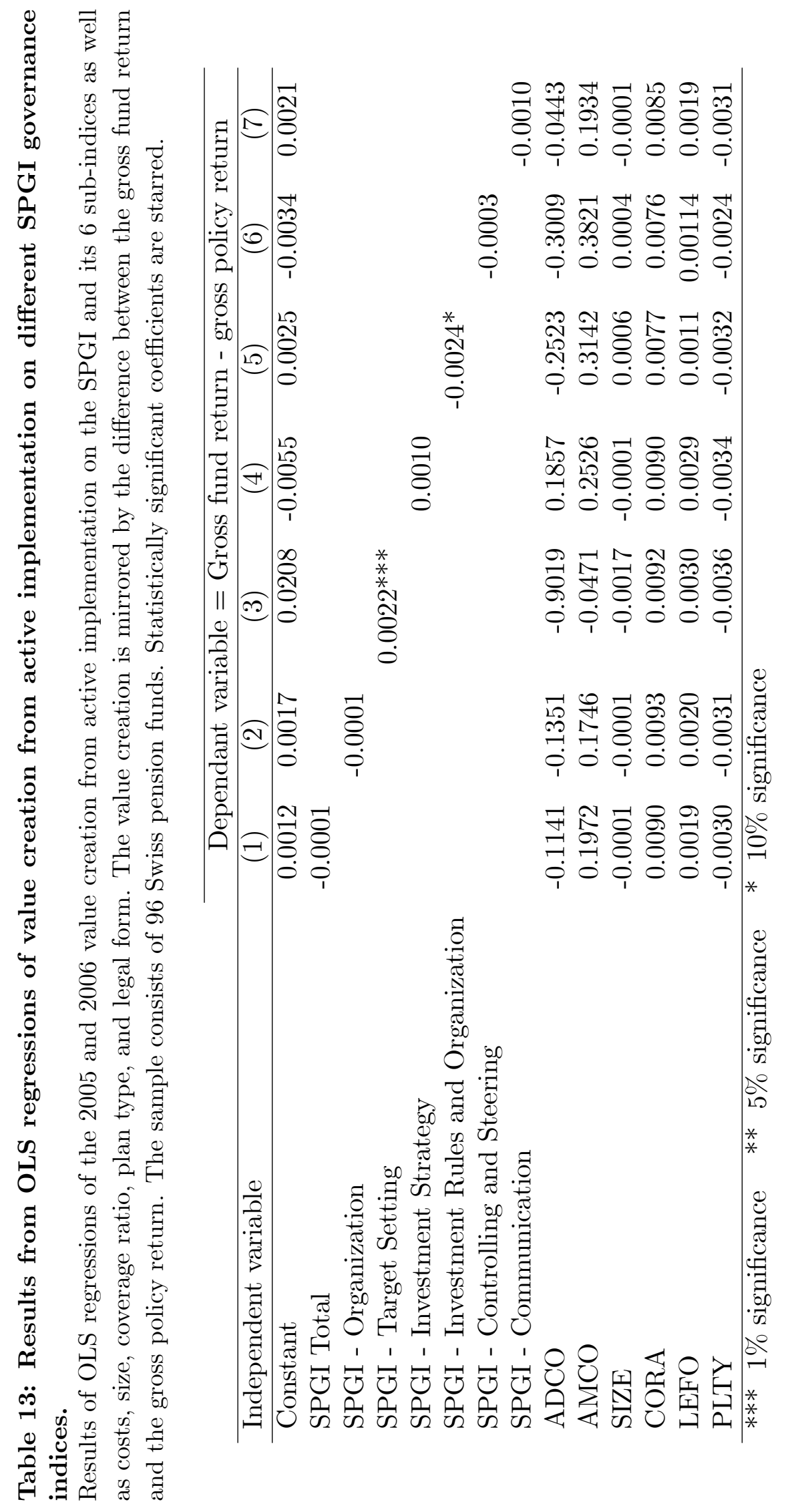


The results in Table 11 show that pension fund governance is positively related to performance. The governance coefficient in equation (1) of Table 11 is significant at the $10 \%$ level. On average, the impact of governance on performance is as much as 9 basis points per index point. In contrast, not all of the six SPGI sub-indices are significantly related to performance, as shown in equations $(2)-(7)$ of Table 11. Only for the two sub-indices SPGI Target Setting and SPGI Investment Strategy, do we find the expected positive relation between pension fund governance and performance. Both sub-indices include important governance elements such as transparency on the target of financing, measurable management objectives, and an investment strategy that is aligned with the target of financing and the risk-taking capacity. The remaining four sub-indices exhibit the expected positive sign. However, the coefficients are statistically not significant. Of the non-governance related variables, only the coverage ratio and to a certain extent administration costs have explanatory power.

Somewhat surprising though, we find no significant influence of good organizational governance on performance. A potential explanation for this finding is that some governance mechanisms are potentially not relevant for both sources of value creation. On the other hand, the effects on the two components of our performance measure may be mutually eliminative. Therefore, we investigate the effect of pension fund governance on the two sources of value creation separately. Table 12 shows the impact of pension fund governance on the first source of value creation, which is the decision on the strategic asset allocation. The results show a positive relation between overall pension fund governance and performance, as shown in equation (1) of Table 12. Again, we find a statistically significant influence only for two of the SPGI sub-indices. The SPGI Target Setting and the SPGI Investment Rules and Organization are positively related to value creation from the decision on the strategic asset allocation.

Table 13 provides the results of the investigation for the second source of value creation. We find no significant effect of the overall governance quality on the outperformance or underperformance of the fund against its policy benchmark. It seems that target setting and investment organization also have a significant influence on value creation from active implementation style. However, good organizational governance is not, as expected, positively related to performance. Pension funds with high values of the sub-index SPGI Investment Rules and Organization tend to have a lower outperformance ${ }^{28}$.

We have found statistically significant relations with performance only for three of the SPGI sub-indices. However, this does not mean that all of the underlying governance mechanisms have no influence on performance. On the other hand, significant SPGI sub-indices are likely to include constituents that do not explain performance. To get a better understanding, we investigate the

\footnotetext{
${ }^{28}$ For the period of investigation, pension funds in the sample show an average outperformance of $0.81 \%$ against their policy benchmark.
} 
effects of individual governance mechanisms on the performance of pension funds, measured by the NVA. For this analysis, we again apply Equation (2). Most governance variables are constructed as dummy variables that take a value of 1 if pension funds comply with good governance as defined by the SPGI. In Table 14, Table 15, and Table 16, we present only the regression results for significant governance variables.

According to our analysis, the SPGI Organization is not significantly related to pension fund performance. However, for 2 out of 10 organizational governance variables, we find a significant influence on performance, as shown in Table 14. Pension funds with a full-time chief executive officer do better according to our analysis. On average, the impact of the chief executive officer on the NVA is as much as $3.6 \%$. In contrast, the pure existence of a separate investment committee seems to have no influence on the performance. However, wherever the investment committee has the optimum size and is therefore capable of acting effectively, there is a positive effect on performance. On the contrary, board size seems to be of little importance. Furthermore, we find no empirical evidence for the recommendation to have external experts in the board of trustees and in the investment committee.

In the OLS regressions, the sub-index SPGI Target Setting is found to be highly significant independent of the applied performance measure. Therefore, it is not surprising that 6 of the 16 significant governance variables are constituents of the SPGI Target Setting. As expected, we find that clear transparency on the target of financing is of great importance. Pension funds that have clear transparency on the minimum required return show, on average, a higher performance. Furthermore, the annual review of the minimum required return also has a positive effect on the performance. Somewhat surprising however, is the fact that management objectives seem to be important for the chief executive officer as opposed to the board of trustees. We find a positive effect on performance for functional specifications and binding objectives for the chief executive officer. Financial compensation of the board of trustees is a controversial topic in Switzerland. On one hand, some authors argue that remunerations may help attract highly qualified and experienced individuals. On the other hand, there are concerns about the integrity of board members who will incidentally, not work on volunatary basis but for the juicy taste of remunerations. We find evidence that such remunerations for members of the board of trustees have a positive impact on pension fund performance. Unfortunately, we are not able to investigate the effect of board compensation that is linked to management objectives since none of the 96 pension funds reported such a compensation scheme. Finally, the code of conduct to prevent the misuse of pension assets seems to have a positive impact on performance.

As shown in Table 15, we find a significantly positive effect on performance for pension funds with a realistic estimate of the expected return of the investment strategy. Furthermore, pension funds with tactical fluctuation margins setting the boundary for tactical asset allocations show on average 


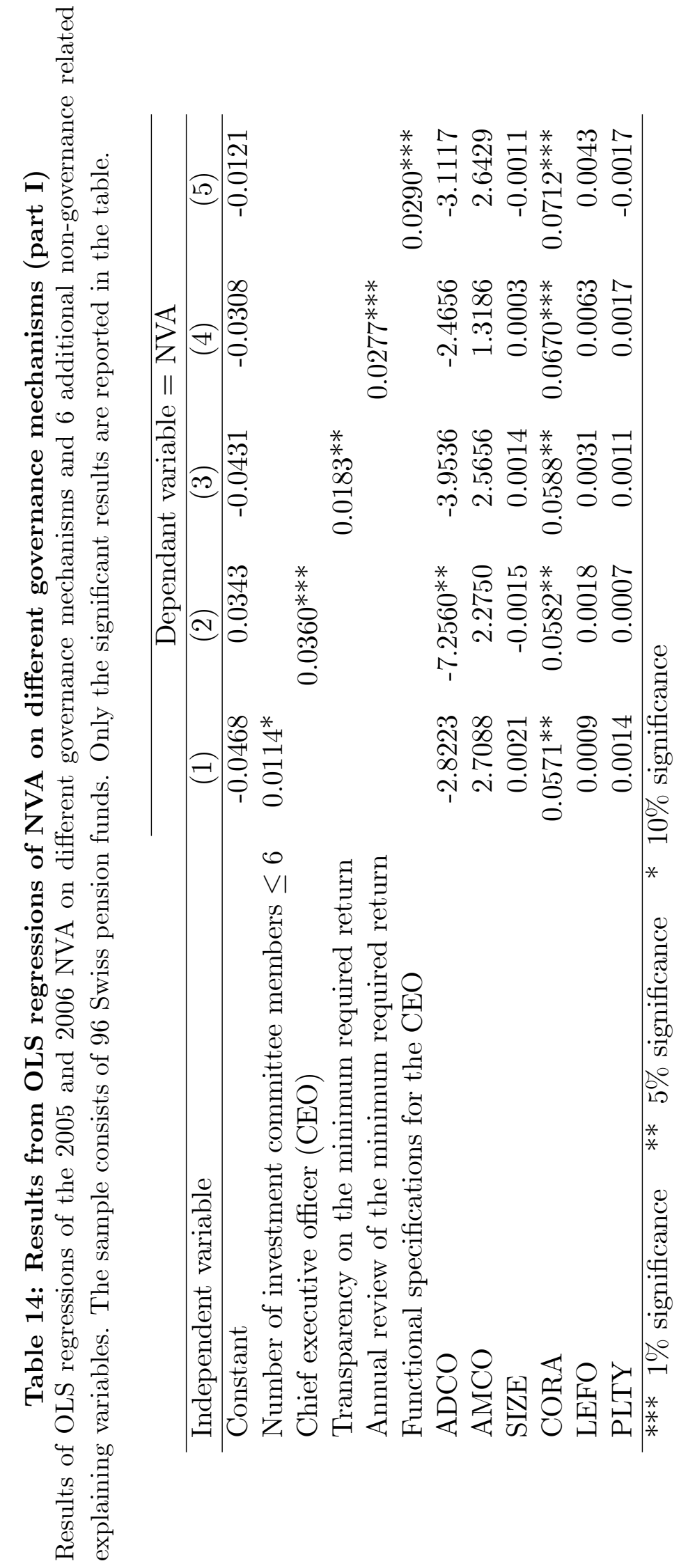




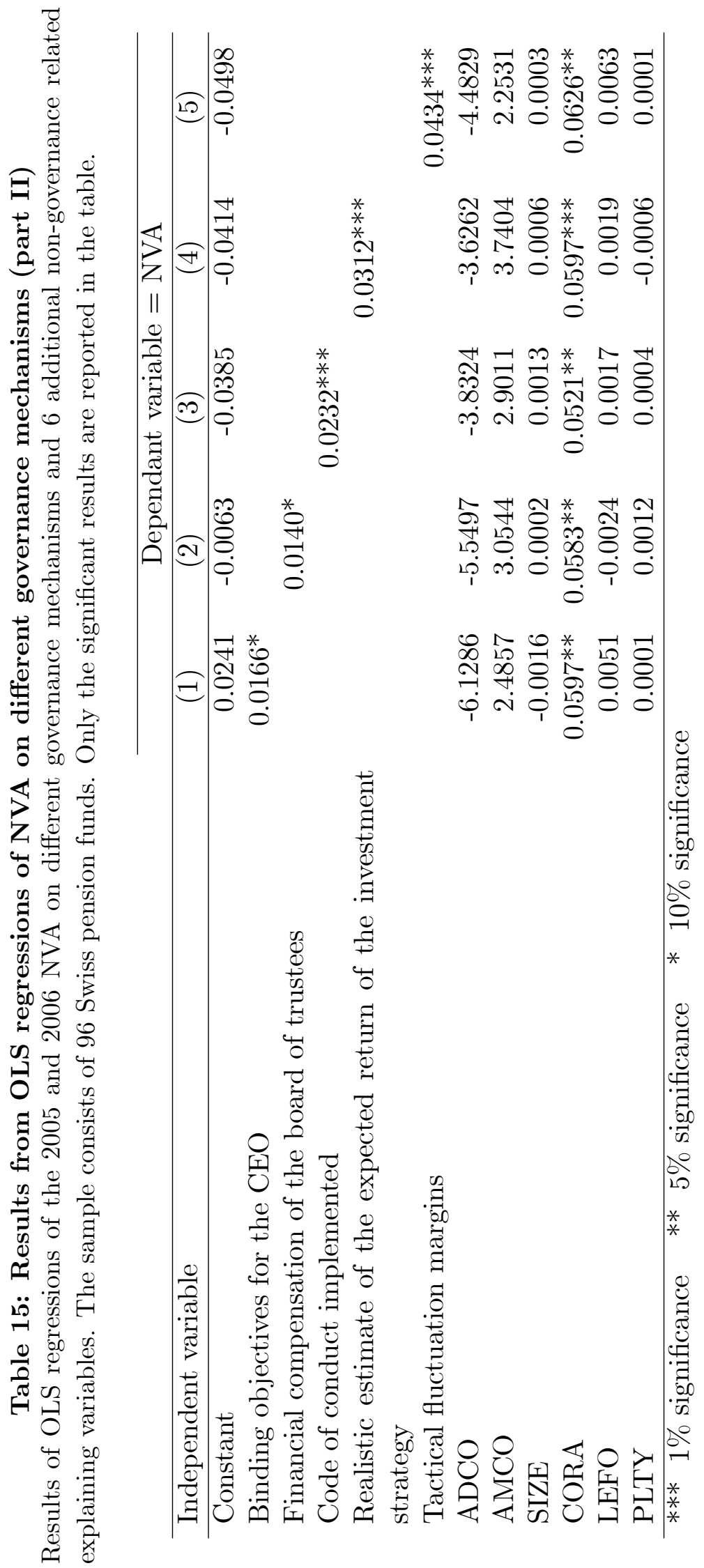




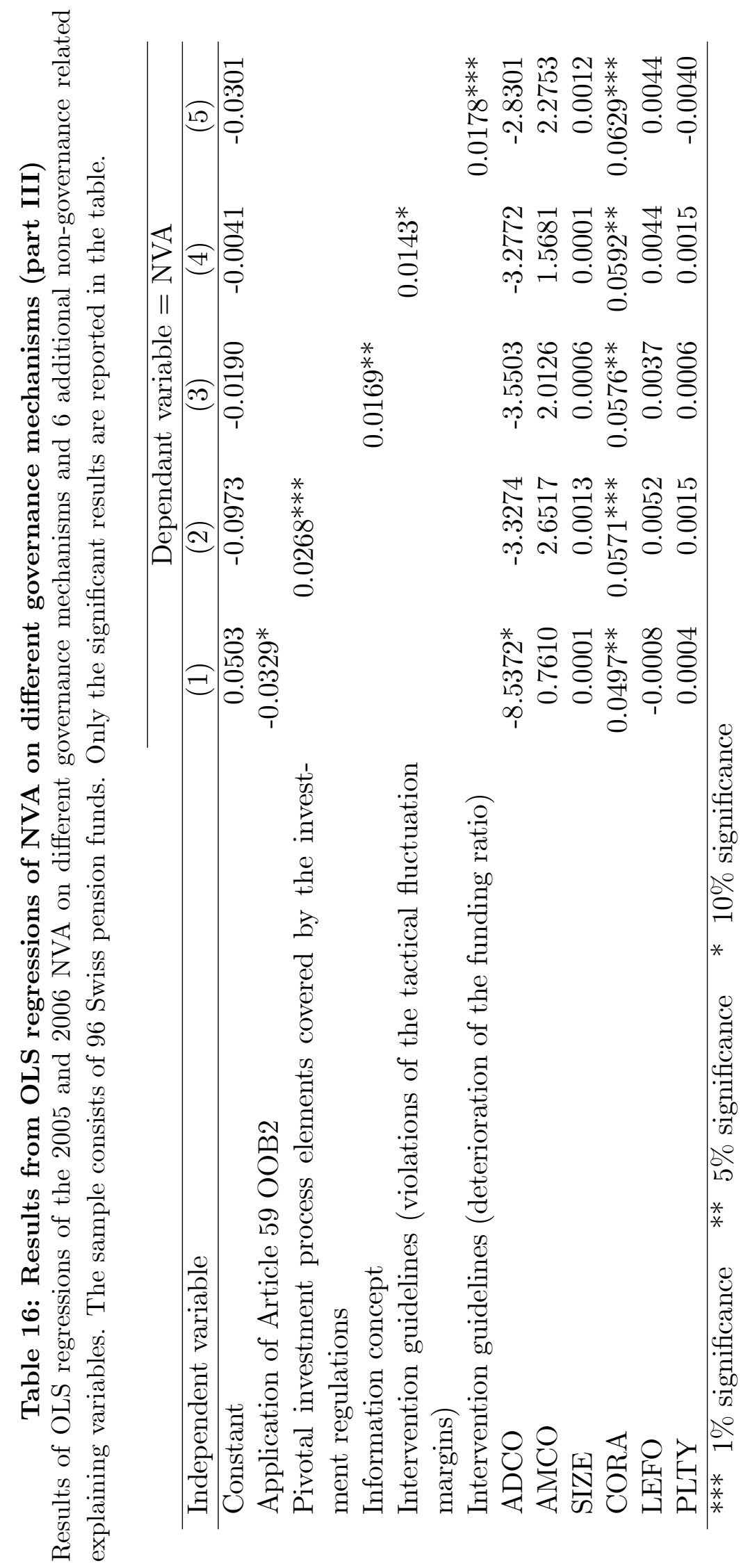


a higher performance. In contrast, the remaining 6 governance mechanisms ensuring that the investment strategy is aligned with the target of financing and the risk-taking capacity of the fund seem to have no significant impact on the value creation of pension funds. This is a rather surprising result given that most authors argue that this is the key requirement for a good governed pension fund. It should be kept in mind however, that we investigate the relation between governance and performance. In contrast, our investigation does not encompass the safety aspect. Many governance variables included in the SPGI are more important for the safety of the retirement income than for the performance of the pension fund. Finally, the application of Article 59 OOB2 seems to have an impact on performance. However, we find a negative impact on performance implying that pension funds, which make use of the possibilities to expand the investment universe, show on average a lower level of value creation.

As our analysis shows, investment organization is an important element of pension fund governance. However, only 1 of $4^{29}$ constituents of the SPGI Investment Rules and Organization has a significant influence on performance. Pension funds, which have all pivotal elements of the investment process covered by their investment regulations, show on average a higher performance.

The SPGI Controlling and Steering contributes the most points to the overall governance index. However, we find a significant impact on performance only for 3 controlling governance variables. It seems to be of high importance that pension funds govern information collection, processing and distribution. For pension funds that have an information concept, we find a higher performance. In contrast, the information frequency seems to be less important. Regular compliance checks and deviation analyses seem to have no significant effect on performance. This corresponds with the findings of Mitchell and Hsin (1994) and Useem and Mitchell (2000) who do not find a link between performance reviews and investment returns of pension funds. Surprisingly, the meeting frequency of the board and of the investment committee seems to have no effect on pension fund performance. In contrast, intervention guidelines both for violations of the fluctuation margins and in case of a significant deterioration of the funding ratio are positively related to performance.

Similar to the SPGI Communication, none of the communication governance variables shows a significant impact on performance according to our analysis.

\section{Conclusion}

We investigate the relationship between pension fund governance and performance. For this purpose, we attempt to define a standard metric that captures

\footnotetext{
${ }^{29}$ The relation between the existence of investment regulations and performance cannot be investigated since all pension funds in the sample report to have investment regulations.
} 
the governance quality of Swiss pension funds. Given the large variety of pension funds in Switzerland, it is clear that there is no universal solution that fits all. Nevertheless, we believe that pension funds do have commonalities and believe therefore that certain standards must exist. The empirical analysis of individual governance mechanisms may provide initial indications on how to improve our initial proposal.

Our results support the widespread hypothesis of a positive relationship between pension fund governance and investment performance. Given our performance measure, good governance with respect to target setting and investment strategy seems to be of particular importance. In contrast, organization, investment rules and organization, controlling and steering, and communication are not significantly related to performance. However, this does not mean that governance issues in these areas are negligible. On the one hand, our index is likely to cover not all important aspects of pension fund governance. For example, the SPGI does not cover soft factors. On the other hand, pension fund governance should not only be aimed at increasing value creation and performance. The safety of the retirement income and mitigation of operational and reputational risks are other important objectives of pension fund governance.

Even though we confine ourselves to defined bounds, in the investigation of the relation between pension fund governance and performance, we identify important elements of good pension fund governance. We find evidence that pension funds should have a full-time chief executive officer. Increasing complexity of the pension system and fast moving capital markets seem to require a further step away from the traditional militia system in Switzerland. Management objectives and financial compensation of the board also imply a further professionalization of the pension system in Switzerland. Looking at the governance variables which have a significant influence on performance, we conclude that size seems to be a real constraint on governance. Over the longterm, it is arguable that pension fund should seek ways of sharing resources or merging into larger entities.

On average, we find no indications of serious governance issues of Swiss pension funds. However, some few pension funds in the sample, in particular small and medium-sized funds, show some serious weaknesses in their governance such as inadequate transparency on the target of financing. We hold the views that all pension funds in Switzerland should comply with certain minimum standards of governance. A broadly accepted pension fund governance index might be a feasible way of setting such a standard. 


\section{Appendix}

Table 17: Benchmark indices by asset class

Overview of benchmark indices by asset class used to estimate the expected return of the 2006 investment strategy.

\begin{tabular}{lll}
\hline Asset class & & Benchmark index \\
\hline Cash & & 3 -month CHF LIBOR \\
Bonds & Domestic & Swiss Bond Index \\
& International & Lehman Global Aggregate \\
Stocks & Domestic & Swiss Performance Index \\
& International & MSCI World \\
Real estate & Domestic direct & KGAST Real Estate Index \\
& Domestic collective & SWX Real Estate Mutual Funds Index \\
& International collective & FTSE EPRA/NAREIT Global \\
Mortgages & & Swiss Mortgage Index \\
Private Equity & & LPX Composite \\
Hedge Funds & & HFRI Fund Weighted Composite Index \\
\hline
\end{tabular}

Table 18: Risk and return of benchmark indices by asset class

Risk, return and reference period of the benchmark indices by asset class.

\begin{tabular}{llll}
\hline Benchmark index & Reference period & Return & Volatility \\
\hline 3-month CHF LIBOR & $96-06$ & $1.53 \%$ & $0.9 \%$ \\
Swiss Bond Index & $96-06$ & $3.77 \%$ & $2.59 \%$ \\
Lehman Global Aggregate & $96-06$ & $5.86 \%$ & $6.94 \%$ \\
Swiss Performance Index & $96-06$ & $10.75 \%$ & $16.83 \%$ \\
MSCI World & $96-06$ & $8.80 \%$ & $18.19 \%$ \\
KGAST Real Estate Index & $97-06$ & $4.56 \%$ & $1.46 \%$ \\
SWX Real Estate Mutual Funds Index & $96-06$ & $5.20 \%$ & $7.13 \%$ \\
FTSE EPRA/NAREIT Global & $96-06$ & $13.90 \%$ & $17.00 \%$ \\
Swiss Mortgage Index & $02-06$ & $3.27 \%$ & $2.28 \%$ \\
LPX Composite & $02-06$ & $11.37 \%$ & $18.01 \%$ \\
HFRI Fund Weighted Comp. & $96-06$ & $11.44 \%$ & $13.22 \%$ \\
\hline
\end{tabular}




\section{References}

Ambachtsheer, K., R. Capelle, and H. Lum (2007): "The State of Global Pension Fund Governance Today," Working paper, Rotman International Centre for Pension Management.

Ambachtsheer, K. P. (1996): "How All Pension Funds Should be Measured," Ambachtsheer Letter 130/131, Toronto: K.P.A. Advisory Services. ley.

Ambachtsheer, K. P., R. Capelle, and T. Scheibelhut (1998): "Improving Pension Fund Performance," Financial Analysts Journal, 54(6), 1521.

Ambachtsheer, K. P., And D. D. Ezra (1998): Pension Fund Excellence: Creating Value for Shareholders. Wiley.

Besley, T., And A. Prat (2003): "Pension Fund Governance and the Choice Between Defined Benefit and Defined Contribution Plans," IFS Working Papers W03/09, Institute for Fiscal Studies.

Bikker, J., And J. De Dreu (2006): "Pension Fund Efficiency: The Impact of Scale, Governance and Plan Design," DNB Working Papers 109, Netherlands Central Bank, Research Department.

Brandenberger, B., And M. Hilb (2008): Pensionskassen-Governance. Verlag Neue Zürcher Zeitung.

Clapman, P. (2007): "Committee on Fund Governance: Best Practice Principles," Discussion paper, Stanford Program in Law, Economics and Business.

Clark, G. L. (2007): "Expertise and Representation in Financial Institutions: UK Legislation on pension fund governance and US regulation of the mutual fund industry," Twenty-First Century Society: Journal of the Academy of Social Sciences, 2(1), 1-24.

Clark, G. L., E. Caerlewy-Smith, and J. C. Marshall (2006): "Pension Fund Trustee Competence: Decision-Making in Problems Relevant to Investment Practice," Journal of Pension Economics and Finance, 5(1), 91-110.

- (2007): "The Consistency of UK Pension Fund Trustee DecisionMaking," Journal of Pension Economics and Finance, 6(1), 67-86.

Clark, G. L., and R. Urwin (2007): "Best-Practice Investment Management: Lessons for Asset," Working papers in employment, work and finance, Oxford University Center for the Environment. 
Helbling, C. (2006): Personalvorsorge und BVG. Haupt Verlag, 6 edn.

Hess, D., and G. Impavido (2003): "Governance of Public Pension Funds: Lessons From Corporate Governance and International Evidence," Policy Research Working Paper Series 3110, World Bank.

Impavido, G. (2002): "On the Governance of Public Pension Fund Management," Policy Research Working Paper Series 2878, World Bank.

Jensen, M. C. (1993): "The Modern Industrial Revolution, Exit, and the Failure of Internal Control Systems," Journal of Finance, 48(3), 831-880.

Lipton, M., and J. W. Lorsch (1992): "A Modest Proposal for Improved Corporate Governance," Business Lawyer, 48(1), 59-77.

Lusenti, G. (2007): "Swiss Institutional Survey," Study report 8, Lusenti Partners, Zurich.

Mitchell, O. S., And P.-L. Hsin (1994): "Public Sector Pension Governance and Performance," NBER Working Papers Series 4632, National Bureau of Economic Research.

Monk, A. H. B. (2007): "The Geography of Pension Liabilities and Fund Governance in the United States," Working paper, Oxford University Centre for the Environment.

Myners, P. (2001): "Institutional Investment in the United Kingdom: A Review," Report, HM Treasury.

OECD (2002): "OECD Guidelines for Pension Fund Governance," Policy guidelines, Organization for Economic Coorporation and Development.

Useem, M., And O. S. Mitchell (2000): "Holders of the Pursue Strings: Governance and Performance of Public Retirement Systems," Social Science Quarterly, 81(2), 489-506.

Yang, T. S., and O. S. Mitchell (2005): "Public Pension Governance, Funding, and Performance: A Longitudinal Appraisal," Pension Research Council Working Paper 2005-2, University of Pennsylvania - Insurance and Risk Management Department.

Yermack, D. (1996): "Higher Market Valuation of Companies With a Small Board of Directors," Journal of Financial Economics, 40(2). 